\title{
Két profil, egy szakma - szociális munkások egymás között
}

\author{
Beszélgetés a Szociális Munka Napja alkalmából dijazott szakemberekkel, Setét Jenövel és \\ Meleg Sándorral szociális munkáról, szociálpolitikáról, fejlesztésekröl és programokról, \\ szakmáról és szakmai identitásról.
}

A Párbeszéd folyóirat szerkesztőségében úgy gondoltuk, hogy az idei Szociális Munka Nap két kitüntetettjét közös interjúra hívjuk. Meleg Sándor az Év Szociális Szakembere, Setét Jenő a Szociális Szakma Érdekképviseletéért díjat vehette át november 12-én. Ezek a díjak fontos visszajelzések és elismerések az érintett szakemberek számára az általuk végzett munka, az általuk képviselt szakmaiság értékeiről, fontosságáról. A már dolgozó és a leendő szociális munkások számára is fontos üzenete van annak, hogy kik a díjazottak, milyen tevékenységek azok, amelyek kivívják a szakmai közösség megbecsülését.

Darvas Ágnes: Szeretettel köszöntelek titeket és gratulálok a dijakhoz. Eddigi szakmai pályafutásotok nem egyforma, már az indulás is más. Sándor közigazgatásból került az önkormányzati szociális szférába, Jenö mindig civilként tevékenykedett.

Meleg Sándor: Nem, nem a közigazgatásban kezdtem. A szakmába úgy kerültem, hogy behívtak katonának és polgári szolgálatra kértem magam, valamilyen humán területre, így kerültem egy önkormányzati szociális intézményhez. Ott a támogató szolgáltatáshoz kerültem, ott fölépítettem a támogató szolgálatoknak a kis körét, igyekeztünk magunk között szakmát fejleszteni. Aztán 2014-ben Czibere Károly vezette államtitkárság szerette volna összehozni egy komplett intézménybe mindazt, ami a szociális szakmának kell a müködéséhez, a képzéstől, a módszertanon keresztül, a különféle programokig, szerintem ez egy nagyon jó koncepció volt, így kerültem az NRSZH-hoz. Aztán úgy kerültem onnan vissza, hogy egyszer csak kiállt az aktuális miniszterelnök helyettes, és bejelentette a háttérintézmények megszüntetését.

Így kerültem vissza az önkormányzati rendszerbe. Most egyébként az önkormányzati intézmények helyzete sem jó, nagyon sok COVID-os feladat rá van terhelve az önkormányzati intézményekre, miközben a fenntartó önkormányzatoknál komoly forráselvonás volt.

Setét Jenő: esetemben is egy kicsi tévedés van, én valóban a közigazgatásban kezdtem. 1992ben érkeztem Budapestre, akkor végeztem a Tündérhegyi szociális munkás, szociális asszisztens képzést, ami később a Wesley szociális munkás képzése lett. A Józsefvárosi Önkormányzat kereteiben létezett egy Józsefvárosi Segítő Szolgálat, ez egy párhuzamos intézmény volt, gyakorlatilag a helyi családsegítő központ társszervezete, de mi valóban az önkormányzat fó épületében, a helyi közigazgatásban dolgoztunk, segítő szakemberekként. Ott kezdtem, Dr. Szőke Judit volt a vezetőnk, ott voltam egy 2 évet, és utána kerültem a Roma Parlamenthez. Annak lett a folytatása a Roma Polgárjogi Alapítvány, ott 15 évet dolgoztam. Ugye a Roma Polgárjogi Alapítványnál alapvetően szociális munkásként dolgoztam, és ez is volt a szakmai identitásom, de emellett jogvédelemmel, és válságkezeléssel is foglalkoztunk, és az így szerzett tapasztalatok birtokában voltam, amikor megszünt a Roma Polgárjogi 
Alapítvány 2010-ben. Gyakorlatilag 15 évet nyomtam le ott egyben. Amikor megszünt a Roma Polgárjogi Alapítvány, akkor meghívott magához a TASZ, a Társaság a Szabadságjogokért, és ezt követően pedig a NEKI nevü szervezet, amit az első kimondottan roma jogvédelmi profilú szervezetként alapítottak. Ez a Nemzeti Etnikai Kisebbségi Jogvédő Alapítvány volt, ennek egykor dr. Furmann Imre volt a vezetője, aki később az Egyenlő Bánásmód Hatóság alelnöke lett, és neves szaktekintély volt. Ezzel párhuzamosan mi elkezdtük 2011-ben az Idetartozunk informális csoportot és mozgalmat, ami mára egyesület lett. Én gyakorlatilag 2010-ig tekintem magamat szociális munkásnak, gyakorló, terepen dolgozó, aktív szociális munkásnak. 2011 óta leginkább civil aktivistaként tekintek önmagamra, vagy polgárjogi aktivistaként. Tehát a szociális munkához, mint szakmához más a viszonyom, napi szinten ma már nincs konkrétan ilyen jellegü munkám, vagy feladatom, de természetesen fontosnak tartom a szociális ügyeket, és magát a szociális munkát is. A Romaversitásnál az ottani szabadegyetemen voltam többször kurzusvezető, tehát mindenféle szervezetek megbízásából dolgoztam, ilyen volt pl. a Partners Hungary.

Most a fóállásom egy nemzetközi szervezet, a National Democratic Institute. Ez egy amerikai külügyminisztérium által alapított nonprofit szervezet, egy nonprofit $\mathrm{kft}$, ahol programszervezéssel foglalkozom. Az igaz, hogy az összes eddigi munkahelyemen leginkább azért alkalmaztak, hogy romákkal dolgozzak együtt, akár szociális munkásként, akár jogvédőként, akár civil aktivistaként, akár szervezőként. Tehát a munkámat elsődlegesen a romák körében végeztem.

DÁ: Ha jól értem, 2011 óta civil aktivistaként definiálod magad. Az mindig definició kérdése, hogy ez most szociális munka vagy sem. Mi minden fér bele abba a bizonyos ezerarcú szociális munkába?

SJ: Amit én csinálok, az az én fogalmaim szerint nagyjából a szociális munkában ismert közösségi munkához, vagy a közösségfejlesztéshez áll közel. Illetőleg 2010 előtt a telep felszámolási program koordinátor párosának egyik tagja voltam, és írtam egy kézikönyvet a telep felszámolás, szegregátum-, gettó-, telep-felszámolás témakörében. Illetőleg több minisztériumnál a kialakítás alatt álló deszegregációs politikában voltam szakértő, és hát persze az egész életem a felzárkózásról szól. Én ezt úgy hívom, hogy roma emancipációs küzdelemről szól, a szó valódi értelmében történő egyenjogúvá válást elősegítő társadalmi változások elősegítéséről.

DÁ: Igen, ez a dij átadásához kapcsolódó méltatásból is kirajzolódik. Érdekes különben a két laudáció összecsengése. Jenötöl elhangzik benne egy idézet, ami arról szól, nem hiszel abban, hogy lesz olyan társadalom, amiben nincsenek elöitéletek, ,, abban viszont hiszek, hogy lehet olyan társadalmat építeni, amiben ezek az elöitéletek nem befolyásolják az egyén boldogulását, nem hátráltatják". Sándor esetében is azt emeli ki a méltatás, hogy felzárkózás központi szociális probléma, de „, a felzárkózási programok nem pótolják, a szociálpolitikai eszközöket, sem a szociális intézményrendszert”. Ezek a kérdések mindig aktuálisak, most talán különösen, hiszen elkezdödött, folyamatban van az ún. 300 település program. Gondolkodjunk kicsit együtt 
erröl. Milyen kifutását, vagy jelentöséget látjátok ennek a programnak? Hogyan látjátok ebben a szociális szférának a szerepét, a szociális munkások szerepét?

MS: Erről tudnék napokat mesélni, én magam most benne vagyok egy ilyen programban, illetve a mesterképzésen szakdolgozati témaként a felzárkózási programok problématérképét választottam, amiben részben sajtóanyagok elemzésére, részben interjúkra, részben pedig a saját tapasztalataimra alapoztam. Jöttek elő bőségesen a különféle problémák, a mondat, amit idéztek, ez lényegében ennek a munkának volt az egyik konklúziója.

Ha megnézem azt, hogy müködnek a terepen ezek a programok, látom, hogy vannak bizonyos szolgáltatási deficitek, akár a felzárkózás irányában, akár úgy általában véve. Amikor megjönnek a felzárkózási források, az önkormányzat és az intézmények azzal kezdik, hogy ezeket a hiányokat elkezdik kiegyengeti ezekből a forrásokból.

Megveszik például a szociális munkásoknak a laptopot, amin egyáltalán tudnak dolgozni, elkezdenek olyan szolgáltatásokat vásárolni, aminek ott kellene lenni a településen már egyébként is, de nincs ott. Ezekböl a forrásokból elöször ezekre megy, és amikor ezek a lyukak be vannak tömködve, akkor merülhet föl egyáltalán, hogy akkor elkezdenek a felzárkózási programmal dolgozni. Ez önmagában egyébként nem rossz, mert valahol eljutunk oda, hogy a végén azzal a célcsoporttal dolgozunk, aki ezeknek a pályázatoknak a célcsoportja. De sajnos olyat is tudnék mondani, ahol maga a felzárkózás egyébként egy teljesen marginális történetté vált. Sok település a saját hiányait ezekből a forrásokból tömködi be, nem lépnek előre, hanem azt finanszírozzák meg, amit az ellátórendszernek saját magának kéne megcsinálnia, lehet ez akár a szolgáltatási infrastruktúra fejlesztése akár a szolgáltatások biztosítása.

SJ: amit Sándortól idéztetek mondatot, az nekem rendkívül szimpatikus, és azzal én mélységesen egyetértek.

Ennek megvan a maga oka, csak előtte még egy gondolat, hogy a szociális munka, mint szakma is egy elég hányatott sorsú szakma, túl azon, hogy magának a szakmának is civil gyökerei vannak. Mégis, most már 2 évtizede azt látjuk, hogy, hogyan próbálják az államosított hatalmi struktúrába egyrészt beigazítani, ami megtörtént, másrészt a kompetenciáit megvágni, vagy éppen áttolni a segítő szerepből, egyfajta hatósági, ellenőrzési szerepbe. Kiváltképp igaz ez a gyerekjóléti szolgáltatások tekintetében.

De magáról a szociálpolitikáról azt gondolom, hogy jelen pillanatban az eredeti célját nem tudja betölteni a szociálpolitika. Tehát nem tudja azokat az egyéni kríziseket kezelni, és enyhíteni, amellyel pl., feloldható lenne az egyénnek a kisodródása, illetőleg szociálpolitikáról akkor tudnánk beszélni, hogyha a társadalmi osztályváltáshoz hozzá tudna járulni. Ami most van, az leginkább egy szegénypolitika, valahol a XIX. századra hasonlító, konzervatív szegénypolitika, ami arra figyel pusztán, hogy a szegények mondjuk, legjobb esetben ne haljanak éhen. De az igazi eszköztár hiányzik. Hogyha a célt úgy határozzuk meg, hogy a szociálpolitika célja nem más, mint az egyén számára mindazokat a társadalmi szolgáltatásokat biztosítani, amellyel ő maga az emberi méltóságát és boldogulását megőrizheti, akkor ebben súlyos hiányok vannak. Mert a kialakult, az államilag, a kormányzat által fenntartott szociálpolitika, az ma leginkább a szociálpolitikáról úgy gondolkozik, mint a bünös szegénység témaköréről, mert hát ugye ők a 
teljes foglalkoztatásra törekednek, és aki ennek ellenére szegény marad, akkor bizonyára ő tehet róla.

Emlékezzünk csak arra, hogy a 2010-es évek közepe táján volt néhány év, nem is olyan régen, amikor a minisztérium államigazgatásában pl., tilos volt kiejteni a szegény szót magát is. Ami persze elképesztő, meg keserü nevetésre ad okot, hogy, hogy kerülhetünk megint történetileg ugyanebbe a fázisba, vagy időszakba, de hát azért mégis csak sokat elárul.

Most én azért értek egyet a Sándor mondatával teljes mértékben, mindenféle udvariasság nélkül esküszöm, mert ez a meggyőződésem. Az a meggyőződésem, hogy leginkább az elmúlt évtizedekben, amikor szociálpolitikáról gondolkodtak, meg akár programokról, akkor mindig a fókusz az úgy volt beállítva, és úgy volt a kérdés föltéve, hogy bizonyára az egyén müködésében van a hiba, és őt kell kidolgozni jó polgárrá, működőképes polgárrá. Miközben a rendszer volt hibás, és a rendszerszintű kirekesztés mechanizmusaival - amit nagyon sok esetben állami erőforrásokkal tartanak fönn, hoznak létre, vagy mélyítenek el -, azzal meg senki nem foglalkozott.

Hát mondok erre egy rendkívül egyszerü példát, ha megengeded, hogy itt vannak pl., a tanodák, igaz, hogy az oktatás területéről, de mégiscsak egy példa. A magyar civil tanodahálózat, ami 200 szereplőből áll, mondjuk, jár 4000 gyerek, hogyha mindenütt van 20 gyerek. Na de azzal a törvényi intézkedéssel, hogy a tankötelezettségi korhatárt leszállították 18-ról 16 évre, a bevezetése óta eltelt 7 évben, 70 ezer gyereket veszítettünk el a közoktatásból 16 éves korában. Tehát egy olyan rendszerszintű intézkedés van, ami a leggyengébb pozíciójú gyerekeket a kisodródás felé tolja el. $\mathrm{Na}$, most ehhez képest, én úgy szoktam ezt megfogalmazni, hogy adhoc módon, és pontszerüen végrehajtott, programszerü beavatkozásokkal nem lehet a kérdést megoldani. Látszólag az enyhítést szolgálja az .., és én nagyon-nagyon becsülöm a civil aktivitásokat, hiszen az egész életem valóban a civil szférában telt el. De lássuk be, hogy bizonyos kérdésekben, az állami beavatkozás kell. Hát, ami azt jelenti ebben az esetben, hogy a teljes társadalom által létrehozott erőforrások újraelosztását, az állam végzi. És ebben a struktúrában bizony olyan intézkedések születnek, amelyek a gyengébb pozíciójú csoportoknak a helyzetét nem javítják, hanem gyengítik, vagy ezt a gyengébb pozíciót bebetonozzák, és létrejön egyfajta status quo. Tehát az újraelosztás, és a rendszerszintü problémákkal senki nem foglalkozik, mert akkor az erősebb szereplővel, az állam magatartásával kellene foglalkozni, és azt kellene megvizsgálni.

És nekem van itt két szerző a fejemben, akiket amikor erről gondolkodom, akkor mindig ilyen origóként használok, az egyik a Kenneth Clark, egy fekete szociológus, a 60-as években, aki megírta a Fekete gettó címü tanulmányát. A másik, ami elementáris erővel hatott rám, és ez nagyon... nagyon-nagyon szinkronban van azzal, amit a Sándor írt, és szóban is elmondott, ez Szalai Júlia tanulmánya, A jóléti fogda. Hogy hogyan válik a rendszer, nem a célcsoport érdekében hadba állítva, hanem hogyan válik öncélúvá, hogyan gondoskodik önmagáról, hogy eltartsa az alsó középosztályban dolgozó embertömeget, ami ugye legalább eggyel a szegénységi küszöb fölött van. 
DÁ: Kérdés, hogy mindez egy önkormányzati intézménynél hogy jelenik meg? Hogy tud egy önkormányzati intézmény a közös értékeink mentén müködni, amikor néha akár a törvények is szembe mennek azzal, ami szakmailag követendö lenne?

MS: Azt tudom mondani, hogy erre jó volt a felzárkózási projekt, amit most csináltunk, nyitott olyan kapukat, amiket egyébként a klasszikus, mondjuk családsegítő-gyerekjólétes vonalon nem tudunk volna megnyitni. Ebben a projektben meg tudtuk vásárolni azokat a fejlesztő szolgáltatásokat és el tudtunk juttatni azokhoz a hátrányos helyzetü gyerekekhez, akikhez egyébként nem jutnának el ezek a szolgáltatások, vagy csak névlegesen. Azt tudjuk, hogy az iskolának biztosítania kell a fejlesztésre szoruló gyerekek, a szükséges fejlesztést, ami vagy létezik, vagy nem létezik, vagy csak papíron létezik.

Ha egy 13 ezres településen dolgozik 5 db szociális munkás, tolva minden létező feladatot maga előtt, ne gondoljuk azt, hogy ezekből a problémahelyzetekből nagy dolgot lehet kihozni. Éves szinten kitermelődik ezen a településen az a 20-30 olyan gyerek, aki alig várja, hogy a nyolcadik osztályt befejezze, vagy még azt se fejezi be. Gyakorlatilag úgy lépnek ki az iskolából, hogy vagy meg se próbálják a középfokú oktatási intézményt, vagy ha megpróbálják, akkor fél éven belül kint vannak a rendszerből.

A 16 éves korhatárhoz annyiban visszakapcsolnék, hogy behozták a szakképzési kötelezettséget, ami szerint az első szakma megszerzéséig kötelező a gyereknek iskolába járni. ${ }^{1}$ Ezzel kapcsolatban az a tapasztalat, hogy magát a jogszabályt se nagyon értelmezik jól, vagy tudják a gyakorlatban használni, a másik dolog, hogy ez megint egy szankcionáló jellegü jogszabály. Ilyen a világon nincsen, hogy ha a gyerek nem megy el iskolába, akkor elkezdem végig büntetni az egész családot azzal, hogy elveszem tőlük a maradék megélhetésüket és szankciókat alkalmazok.

Lehet tudni, hogy sok gyerek azért esik ki az oktatásból, mert 16 évesen már például a mezőgazdasági munkákban van kint a családdal, és olyan jövedelmet termelnek, amiből a család ott él. Ha szezonális munkákra összeáll a család, akkor olyan jövedelmet tudnak termelni, amiböl meg tudnak élni. Az más kérdés, hogy ez részben szürkegazdaság, részben feketegazdaság, és pont a COVID-os válság erősen megmutatta, hogy mennyire sérülékeny a foglalkoztatási helyzet.

Amikor mi szerveztük a hiányzó 7. és 8. osztályos képzést teljesen ingyen és a településen helyben, akkor $2 \times 40$ emberből 5 vagy 6 jött el a képzésre. A távolmaradók mindegyike elmondta nekünk, hogy ők most aktuálisan dolgoznak. Azt is elmondták, hogy ők most ebből teljesen jól megélnek, ki bírják fizetni az albérletet, ami igaz, hogy nem szabályszerü, inkább szívességi lakáshasználat jellegü, de tudják fizetni, megvannak a megélhetési költségek is, és

\footnotetext{
${ }^{1}$ 2019. évi LXXX. törvény a szakképzésről

71. § [A kiskorú tanuló törvényes képviselöjének kötelességei]

(2) A kiskorú tanuló törvényes képviselöje - gyermeke vagy a nevelése alatt álló kiskorú tanuló gazdasági és társadalmi életben való önálló részvétele esélyeinek elősegítése érdekében - köteles gondoskodni arról, hogy a tankötelezettségét teljesített kiskorú gyermeke vagy a nevelése alatt álló kiskorú tanuló kimaradása esetén tizennyolc éves koráig, de legalább egy részszakma megszerzéséig tanulmányokat folytasson. Ha a kiskorú tanuló törvényes képviselöje e kötelezettségének nem tesz eleget, a gyermekére vagy a nevelése alatt álló kiskorú tanulóra tekintettel járó valamennyi támogatás nyújtása a részszakma megszerzéséig szünetel. A foglalkoztató megszüntetheti a kiskorú tanuló foglalkoztatásra irányuló jogviszonyát, ha az a kiskorú tanuló tanulmányai folytatásával nem összeegyeztethető, vagy a foglalkoztatásra irányuló jogviszony fenntartása az e bekezdés szerinti cél megvalósulását kizárja.
} 
gyakorlatilag a saját fejük után tudnak menni. És én ilyenkor hiába mondom, hogy várjatok, majd ez pár év múlva azért probléma lesz. Szerveztünk volna szakmaszerző képzést is, de ha most ha ő elvégzi ezt a képzést, akkor hivatalosan bejelentett munkában megkeresi a bérminimumot, most viszont ő a fekete-szürke foglalkoztatásban ennek a kétszeresét keresi.

SJ: annyit szeretnék megjegyezni, hogy lehet, hogy az én általam elmondottakból egy picit úgy tűnt, mint hogy ha szembe állítanám a programszerü, és a rendszerszintű beavatkozásokat egymással, ami nem így van. Tehát én rendkívül fontosnak tartok minden egyes programot, ami ezekre az ügyekre irányul, csak nem tartom elegendőnek. Tehát nagyon-nagyon fontos, csak szerintem nem elégséges, erre szeretnék rámutatni. A szereplők összességéből az államot üzemeltetőkre, a mindenkori államot üzemeltetőkre, hogy mennyivel nagyobb a felelősségük abban, hogy milyen társadalmi hatású döntéseket hoznak, és mennyire lesz a szociálpolitikának eszköztára, beavatkozási mozgástere. Tehát én minden egyes civil programot, ami segíteni igyekszik az egyénnek, a családoknak, a gyerekeknek, azt én nagyra értékelem, azt is mondhatnám, hogy el tudom fogadni a Bibliai Szodoma és Gomora elvét, hogyha csak egy embernek is segít, akkor az már fontos. $\mathrm{Na}$ de ettől még a rendszer hibáira, problémáira, és visszásságaira rá akarok mutatni. Illetőleg amit most Sándor elmondott, az teljesen életszerü, teljesen így van, de azt gondolom, hogy a szociálpolitikát üzemeltető kormányzatoknak az igen is felelőssége, hogy ezeket a tendenciákat merre tolják el, az erőforrásokat hova célozzák az újraelosztásban. Tehát, hogyha egyszer úgy fog dönteni a kormány, hogy a jelenleginél százszor több informatikus kell, és ehhez százszor több oktatási helyet alakít ki, százszor több ösztöndíjjal és mindenféle ösztönzőkkel, akkor én állítom, hogy lesz százszor több informatikus. Tehát ezzel csak azt akarom állítani, hogyha a legszegényebb családok gyermekei, legyenek azok romák, nem romák, tehát kizárólag abban a kategóriában gondolkodom, hogy jövedelmi szegények gyerekei esetében el akarjuk érni, hogy megszakítsuk a generációs szegénység láncolatát, és egy más társadalmi pozíciót, státuszt foglaljanak el, akkor oda igen is be kell fektetni, pl., az oktatásukba. Na most míg a kérdést úgy tesszük föl, hogy vagy elmegy a gyerek iskolába és akkor nem eszik, vagy nem megy el, és akkor eszik, és életben maradnak, addig az nem egy tisztességes kérdésfeltevés. Tehát úgy kell föltennünk a kérdést, hogy ha ugyanannyi ösztönzőt teszünk a legszegényebb státuszú családok gyermekeinek iskoláztatása mellé, amely képes kiváltani ezt a fajta feketegazdaságbeli kiszolgáltatottságukat, akkor vajon végigcsinálja-e?

És ez jó kérdésföltevés, nekem erre személyes példám is van. Amíg nős ember voltam - nagyon fiatalon házasodtunk össze -, a feleségemnek 8 osztálya volt, nekem szakmunkás végzettségem. Már nagyocskák voltak a gyerekeink, és jött egy állami program, az volt a címe, a neve, hogy Lépj egyet előre. Ebben gyakorlatilag 1 havi bérrel egyező támogatást tettek, a szakmát szerezni vágyók támogatása címén. A feleségem elment, és kitanulta a fodrász szakmát, és minden hónapban hazahozott annyi pénzt, ami a fizetése lett volna, hogyha elmegy akár feketén, akár legálisan dolgozni. Tehát nem kellett döntenünk, hogy eszünk, vagy tanulunk, hanem a feleségem megszerezte a fodrász szakmát, utána leérettségizett, és nagyon igyekeztünk, hogy hamarabb érettségizzünk le, mint a gyerekeink, hogy legyen valamilyen motiváló erő. Úgyhogy mind a ketten felnőtt fejjel érettségiztünk le, már bőven nagyok voltak a gyerekeink. De az ő példáját azért mondtam el, mert a személyes életemben tapasztaltam meg azt, hogy nem kellett 
a között döntenünk, hogy akkor vagy én leszek kizárólag a családfenntartó, és abból az egy fizetésből kell megélnünk négyünknek, mert a feleségem ugyanannyi pénzt hozott haza azáltal, hogy szakmát szerzett, amíg tanult, mint hogyha dolgozott volna. Tehát szerintem ez a megoldás kulcsa, és mindent megértek. Öszintén mondom, hogy én minden voltam az életemben. Hajlék nélküli ember, nélkülöző, szegénységben élő felnőtt ember. Gyerekként nem, mert jó módban éltem a szüleimmel. De felnőttként voltam nélkülöző, és szegény ember, ma sem vagyok gazdag, de nincsenek napi létfenntartási problémáim. De nem tudom eltagadni ebben az állam felelősségét, és megkerülhetetlen felelősségét ebben a történetben.

Ugye van a korábbi brazil elnök példája, Lula da Silva aki a 2000-es években volt elnök, aki attól írta be magát a történelembe, hogy az állami szociálpolitikai intézkedésekkel elérte, hogy a szegények 20\%-át tolta át a szegénységi küszöb fölé. Tehát Magyarországnak nem lehet érdeke az, hogy állami forrásokon állítsuk elő a jövő reménytelen szegényeit, akik majd újra sorba állnak a Munkaügyi Hivatalokban, a segélyezési irodákon. Márpedig 71 ezer gyerek kiesett a közoktatásból, mindenféle érdemi iskolai kompetencia, és tudás nélkül úgy, hogy közben a GDP jelentős részét költjük el a közoktatás fenntartására.

És akkor behozok egy másik szempontot, amit adatokkal nem tudok alátámasztani, csak a gondolat erejéig vetek föl, hogy számos egyetemi oktató barátunk, ismerősünk van, akik őszintén elmondják, hogy a magyar társadalom fiataljai, és gyerekei közül, az államnak az egyetemisták kerülnek a legtöbbe. És ott nem kérdés, hogy ezeket a támogatásokat, erőforrásokat továbbra is biztosítjuk-e annak érdekében, hogy Magyarországnak a jövöre nézvést nemzetközileg is versenyképes tudással rendelkezö, iskolázott, kimüvelt fiatalok legyenek a polgárai. A legszegényebbek esetében a társadalmi hierarchiában legalul elhelyezkedők esetében eltekintünk ettől, és úgy teszünk kicsit össztársadalmi szinten, mint, hogyha kvázi az egyén boldogulása, és sikeressége, az kizárólag az egyén felelőssége lenne. Természetesen az egyén törekvése, és felelőssége nem megspórolható a történetből, tehát kell, hogy az érintett legalább akarja, és legyen benne törekvés, de nem kizárólagos. Nagyon-nagyon sok múlik a társadalmi klímán, környezeten, és van-e ehhez támogató eszköztár, vagy nincs egész egyszerüen. Tehát mi, jelenkori adófizetők, és honpolgárok, és szavazó polgárok döntjük el a szavazatainkkal pl., vagy az akaratunk kifejezésével, hogy a jövő nemzedékének mekkora része lesz reménytelenül szegény, vagy sikeresebb a többi csoporttól.

És ez az a fajta egyenlőtlenség, amely engem foglalkoztat, és amely hát aktivitásra késztet, mert igaz, hogy én döntő többségében a roma civil önszerveződésben, a romák emancipációs küzdelmében dolgozom, de sziklaszilárd meggyőződésem, hogy amikor a romák egyenjogúságáért, és sikerességéért, felzárkózásért dolgozunk, akkor Magyarország jövőjeeért dolgozunk, Magyarország sikerességéért dolgozunk.

MS: A saját tapasztalataim alapján azt tudom mondani, hogy azért is gond, hogy ezt a társadalmi réteget nem segítjük az előrelépésben, mert ez egy iszonyatos humán erőforrás pazarlás. Magyarországnak ahhoz, hogy mondjuk gazdaságilag, társadalmilag fejlődjön, kellenének a XXI. század szakmáira készségeivel fölvértezett fiatalok. A három éves programunk alapján elmondhatom, hogy elképesztő mennyiségü tehetséges gyerek van a 
szegények között, semmivel nem rosszabb úgymond a merítés mint mondjuk egy középosztálybeli családnál.

Nagyon jó kézügyességü gyerekek vannak, jól számolnak, nagyon jó ösztönszerü technikai készségekkel bírnak. Azt viszont látjuk, hogy a társadalmi helyzetből fakadóan, illetve az, hogy az iskolában ezek nincsenek ilyen szinten fölkarolva, nincsen beléjük invesztálva. Nincs mögöttük az a folyamatos támogató háttér, amit a szülök nem tudnak megadni. Így ezek a tehetségek szépen lassan elporladnak, és gyakorlatilag kiesnek a rendszerből. Még azt se tudom mondani, hogy nem akarnak a gyerekek, mert elvittük őket egy foglalkozási kiállításra, és minden gyerek úgy jött haza, hogy ő rendőr akar lenni, hogy ő tüzoltó akar lenni, vagy informatikus vagy ürhajós akar lenni, tehát megszólította őket ez a dolog, a készségeik megvannak.

A legrosszabb helyzetü, gettóból érkező leányzónak olyan kézügyessége van, hogy azt mondtuk, hogy minimum cukrásznak kéne állnia, mert az a tortadíszítési készség, ami benne van a kezében ösztönszerüen, az tényleg lehetőséget adna neki, hogy ki tudjon törni. Ami ebből a szempontból egyrészt szomorú, másrészt felháborító, hogy ebbe a társadalmi közegbe öntjük bele a forrásokat, a végeredmény mégis az, hogy ezek a gyerekek elindulnak fölfelé, utána viszont lekanyarodnak és eltünnek. Holott ott a rengeteg tehetség! Ez a rengeteg gyerek, aki így most elveszik, képes lenne Magyarországot fölemelni. Lehetne közöttük világraszóló művész is.

DÁ: Hogy látjátok, azok az anyagi eröforrások, amelyeket az ország célzottan a legrosszabb helyzetüek körülményeinek és lehetöségének javitására fordit, hogy alakulnak az elmúlt időszakban? Egyrészt a költségvetési forrásokra gondolok, másrészt az uniós pályázati forrásokra. Hogy lehetne ezeken a területeken komolyabb áttörést elérni?

SJ: Meggyőződésem, hogy az elmúlt 10-12 évben a nemzeti jövedelem tekintetében a legtöbb kivonás, az a legalul elhelyezkedő társadalmi csoportoktól történt meg. Konkrétan ellátások szüntek meg, illetőleg magával, azzal az egyetlen lépéssel, hogy a szociális ellátások változatlanok maradtak, nem lettek értékállóak, és inflációkövetőek. Gondoljunk bele, hogy a legkisebb öregségi nyugdíj és a családi pótlék 12 éve változatlan. Az előbbi a szociális ellátások viszonyítási küszöbe, a jogosultságok alapvető kritériuma. Tehát magával ezeknek a változatlanul hagyásával megnövelték a társadalmi ollót, és van itt egy hazugság, mégpedig az, hogy egész egyszerüen tudomásul kell venni, hogy a gazdagokra sokkal több pénzt fordít ez az állam, mint a szegényekre.

Van itt egy másik hazugság, amit az ország szeretett önmagának bemesélni, több mint 20 éven keresztül, hogy a magyar állam minden gyereket egyformának tekint. Ez nem így van. A szegények gyerekei kapnak egyszeres családi pótlékot, a gazdagok gyerekei pedig a családi pótlékon kívül, más társadalmi jövedelmek útján ennek a sokszorosát. Tehát ilyen pl., az adókedvezmények, amellyel önmagában nincs bajom, hogy valaki adókedvezményt kap, csak akkor olyan szociálpolitikát kell folytatni, ami a szegényekhez is eljuttat társadalmi jövedelmeket. Persze mondhatja azt valaki, hogy ez a világ régi törvénye, hogy a szegények szegényednek, a gazdagok meg gazdagodnak, csak a szociálpolitika az pont ezen akar 
változtatni. Tehát az nincs rendjén, hogy folyamatosan a kivonás az a szegényektöl történik, és az újraelosztás pedig fölfelé, a gazdagok felé történik.

Mondok erre nagyon egyszerü példákat. Én azt gondolom, hogy korábban a szociálpolitikának, és a szociális munkának fontos vívmánya volt egy új szakma, az adósságkezelés megszületése, a hátralékos háztartások normatív alapú megtámogatása. De hát ugye az egész szociálpolitikában történt egy állami kormányzati fordulat, míg mondjuk 90 után az volt az innováció, hogy az érdemesség helyett, a rászorultság elve volt a domináns, most visszatértünk az érdemesség elvéhez, ami ugye egy nagyon szubjektív megítélés, hogy ki az, aki megérdemli az állam segítségét, és ki az, aki nem. Ez pont a rászorultság elvével szakít, amelyet én nem támogatok, és azt gondolom, hogy miközben kivonja az állam a forrásokat az alul lévő társadalmi csoportok köréből, legyenek ezek a dolgozói szegénységben, mélyszegénységben, vagy a gyermekszegénység problémájával küszködők, aközben szeretné magát egyfajta keresztény, humanitárius szerepben tetszelegtetni. De közben megszünt az adósságkezelés, a lakásfenntartási támogatás, elértéktelenedtek a szociális transzferek, és a segélyezés, mint olyan. Egy nagy része visszakerült az önkormányzati szintre, ahol én erre láttam konkrét példát egy cigány többségü faluban, ahol a nem cigány polgármesterrel interjúztam, hogy akkor most, hogy visszakerült az önkormányzati hatáskörbe, akkor, hogyan, milyen tapasztalatai vannak. És ahogy visszakerült, azonnal a helyi ellátásokat a nyugdíjasok felé transzponálta, mert ők kielégítik az érdemességi kategóriáját, és a legmegbízhatóbb szavazóbázis.

Ez nem azt jelenti, hogy én nyugdíjas ellenes vagyok. Rendkívül igazságtalannak tartom, hogy több százezer nyugdíjasnak a nyugdíja 100.000.- Ft alatt van. De az nem járható út, hogy a szegényeket szembe fordítjuk egymással, és megversenyeztetjük őket a szűkösen elérhető állami forrásokért, és a legszegényebbek pedig kívül rekednek ezen a versenyen, föleg, hogyha láthatóan romák, és főleg, hogyha többgyermekes roma családokról beszélünk. Mert bizony nem lehet tagadni, hogy a szociálpolitikai újraelosztást is áthatják az elöítéletek, és ki merem mondani, hogy a rasszizmus is. Hiszen azzal találkozunk, hogy a kormányzati szervezés szintjén meg merik mondani, hogy azért nem vezetünk be alapjövedelmet, meg azért, úgy szabjuk az otthonteremtési támogatás feltételrendszereit, hogy a közmunkások lehetőleg kiszoruljanak belöle, mert mindenki tudja, hogy akkor azok a jövedelmek hova jutnának el. Ez a felkiáltás. Ez egy masszívan rasszista tétel egyébként, amit a társadalom villámgyorsan és könnyen dekódol. Most az a helyzet, hogy az etnikai elóítéletek mentén lehet eladni a társadalom egészének az egyébként generálisan szegényellenes intézkedéseket. Mert mindenki azt gondolja, hogy pusztán a cigányokra vonatkozik, ami nem így van, de a körítés, a retorika az ez.

MS: Nálunk minden évben felmerül, hogy milyen kis összeg a települési támogatás keretösszege, milyen kis része ez a költségvetésnek. Minimális összegek vannak, csak jelképes jellegüek, ebből biztos, hogy nem lehet nagyon elörébb jutni. Azt viszont hozzá kell tenni, hogy amikor nagyon indokolt eset van, akkor lehet komolyabb támogatást intézni. Volt rá példa, hogy haláleset volt a családban, leégett egy ház, és akkor ehhez nagyobb összeget adott a település. 
MS: Igazából az a prioritás, hogy egyetlenegy család se tudjon olyan mennyiségủ támogatáshoz jutni, ami vélhetőleg a támogatás felé mozdítaná őket. Limitálva van, hogy hány alkalommal, mekkora összeget kaphat. Ha ezt fölszorzom, meg összeadom, akkor ebből egy nagyobb bevásárlást sem lehet megcsinálni. Ténylegesen egy nagyon minimális, krízissegély jellegü a támogatás. Azért volt ezen a téren sikerélményeim, sikerült elérni, hogy a téli tüzifának az addig kissé kaotikus kiosztása rendezetté vált. Tényleg voltak olyanok, akik próbáltak trükközni, pl. külön-külön eljött a család minden tagja a tủzifáért. Hogy ne legyen visszaélés, meg egyéb problémák, sikerült teljesen jó, korrekt mederbe terelni a folyamatot, ami azóta müködik is szépen.

Amit én viszont a programokhoz hozzáfüznék: azt gondolom, hogy ahhoz képest, hogy korábban mennyi forrás ment erre a területre, most kifejezetten sok jut ide. Több tízmilliárd Ft megy különféle programokon (EFOP, TOP, stb.) a felzárkózási területre, viszonylag sokan pályáztak is, nagyságrendileg 200 településen müködnek ilyen programok. Összességében, ebből lehetne valamit elérni. Én magának a pályázati rendszernek a betegségeit látom a legnagyobb akadálynak, emiatt nem tudnak a programok hatékonyan müködni. Például 2-3 év alatt, akármennyire jó egy program, nem lehet megváltani a világot, nem lehet például végig kísérni a gyereket az iskolai időszakán keresztül, hogy ne morzsolódjon le. Nem lehet egy családot végig kísérni egy gyerek fölnevelésében, hogy ök stabilan ki tudják alakítani azokat a normalizált szülői szerepeket, amit elvárna tőlük a társadalom. Ki lehet építeni egyfajta bizalmat, gyakorlatilag erre kellene a következö lépést ráépíteni. Igazából nem is a pénz mennyisége lenne a fontos, hanem az időtartam, hogy ott tudjunk lenni a családokkal, és tudjuk őket segíteni.

A legtöbb pályázati program az 3-4 év, ebből most ki kell vonni ezt az évet, mert ez a COVID miatt gyakorlatilag elveszett, az a típusú kapcsolat, amit fölépítettünk mondjuk 2019 végéig, az 2020-ban gyakorlatilag le is épült. A másik dolog, ami nagyon fontos lenne ehhez, és ez csak részben pénzkérdés, hogy ezek a programok akkor müködnek, ha ott vannak a szakemberek, akik dolgoznak benne. Nem is az a kritikus pont, hogy ebbe mennyi pénzt öntünk bele, hanem, hogy van-e egyáltalán szakember, aki dolgozzon ezekkel a családokkal. Most, Magyarországon nincsenek szakemberek, nincs utánpótlás, mert a szociális munkás képzésekben néhány fös évfolyamok futnak, és akik végeznek, azok közül is sokan rövid időn belül elhagyják a pályát. És akkor ott vannak a szerepkonfliktusok: adott egy szociális munkás csapat, aki ellát gyerekjóléti feladatokat, amiben játssza a ,szociális rendőrt”, kimegy a családhoz, védelembe vétel van, tessék bevásárolni, intézni a gyereknek ezt, azt, amazt. Közben meg a felzárkózási oldalról neki nem ott kellene lenni, hanem a család mellett, szövetségesként, hogy mit lehetne itt kiharcolni a rendszerből, vagy miben tudnánk előre lépni. Én ezt egy olyan szerepkonfliktusnak érzem, ami szerintem komoly probléma.

Vecsei Miklósnak is volt egy érdekes nyilatkozata a diagnózis alapú szociális munkáról, hogy ahol nincs védőnő, oda visz. Kérdezem: honnan? ha talál, akkor hozzon már nekünk is. Nincs szakember, azon szinten müködnek az ellátórendszerek, hogy az egyik helyről elcsábítjuk az ott lévő szakembereket a másik helyre, ahonnan majd tovább csábítja más. Egy rendszert nem 
lehet müködtetni, hogy egymás elől happoljuk el a megmaradt néhány szociális munkást, aki még dolgozik az országban.

SJ: Reagálnék 2-3 pontban röviden. Én nagyon fontosnak tartom a Sándor példáját a szociális tűzifa ügyről. Nagyon jól megmutatja a rendszer problémáit. Ugye a szociális tüzifa program úgy van kitalálva, hogy az 5000 fő alatti településekre lő. Na de mi van az 5000 fő településnél nagyobb településeken nélkülözőkkel, hogyan kezeli a szociálpolitika azt a problémát, hogy évröl-évre mondjuk több száz nyugdíjas vagy időskorú ember fagy meg az otthonában különböző méretü településeken. Hogyan kezeli a szociálpolitika azt a problémát, hogy évrőlévre szerintem 100-as nagyságrendben vannak olyan tüzesetek, amikor a családok az otthonaikat elvesztik, és senki nem tudja, hogy mi történik velük, illetőleg az állampolgárok szolidaritására vannak bízva. Ez az egyik állításom.

A másik, amiről szót kell ejtenünk, ez a települési egyenlőtlenségek a szociálpolitikai szolgáltatások tekintetében. Tehát pl., az, hogy a kistelepüléseken a családsegítés, vagy a gyermekjóléti tevékenység, az heti 1x1 óra, 12 és 13 óra között, és én jártam ilyen kisfaluban, ahol így volt belőve, hogy 12 és 13 óra között lehet találkozni a családgondozóval, pont ebédidőben. Tehát, hogy ezeken a településeken ez is egy strukturális egyenlötlenség, hogy ugyanannak az államnak a polgárai, más mennyiségü-minőségű szolgáltatást kapnak, sokkal kevesebbet.

A harmadik témakör, amit érintettetek, a 300 felzárkózó település programja. Ez nekem azért fontos, mert a mi egyesületünk, az Idetartozunk Egyesület, 8 évvel ezelőtt, bizonyíthatóan, írásban megfogalmazta a, fogalmazzunk úgy, javaslatát vagy követelését. A 2010 előtti LHH program, ami a leghátrányosabb helyzetű kistérségek programja volt, tapasztalata volt a nekem is, mint abban dolgozó szakértőnek, hogy a hátrányos helyzetű térségeken belül is, a kistelepülések, szegényfalvak, és gettó települések kiszorultak az uniós források eléréséből. Ezért tettük azt a javaslatot, hogy a 300 legszegényebb magyar települést a kormány a pályázati elosztó versenyen kívül, önállóan támogassa. Csakhogy most, ez a felzárkózási programmal, ma több probléma is van az én olvasatomban. Az egyik az, hogy - és ez egy roma civil önszerveződési vagy mozgalmi szempont -, hogy az állam és a kormány kegyeit kereső roma szervezeteken, és az országos roma önkormányzaton kívül, ami kormány fiókszervezete, a roma önszerveződés résztvevői semmit nem tudnak erről a felzárkóztatási programról, amelyik egyébként a legizmosabb program lesz költségvetését tekintve. Tehát ide fog elmenni a legtöbb pénz úgy, hogy közben semmit nem tudunk a tartalmáról. Én több körben találkoztam Vecsei Miklóssal és munkatársaival, akikkel szerintem egy élhető, jó, egymás iránt tiszteletet tanúsító viszonyunk van, de ettől én még fel szoktam tenni a magam kérdéseit, az összes nagyrabecsülésem mellett is. Nem tudjuk, hogy ennek a programnak mik a normatív szabályai, mik a jogosultságai, hogyan lehet egy településnek bekerülni, ott mit kap. Ami hozzám eljutott belőle tudás, az annyi, hogy ezeken a településeken, a helyben élők igényeire próbálnak reflektálni. Ha valakinek nincs cipője, akkor vesznek neki cipőt, ha valakinek nincs kabátja, vesznek neki kabátot. Most megint az a kérdés, hogy szociális munkás múltú családgondozóként támogatok-e egy ilyet? Természetesen igen. De ettől még azt a területi leszakadás, amivel ezek a települések küzdenek, hogy nincsenek helyben családgondozók, 
nincs közvilágítás, nincs út, nincs csapadékvíz-elvezetés, nincs szemétszállítás, tehát ezek a leszakadások megmaradnak. Ezek a rendszerszintü szolgáltatások, amiket mondjuk egy nagyobb településen élö állampolgár tök természetesen él meg, de ők nem is találkoznak vele. Ezekre a rendszerszintű hiányokra ez a program nem reflektál. És ha ennek a programnak, ami a legerősebb költségvetéssel fog bírni, az erőforrásait elkótyavetyéljük, hogy így fogalmazzak, kizárólag egyéni esetkezelésre és családgondozásra, akkor persze rövidtávon van valami felmutatható, hogy 50 családnak adtunk élelmiszercsomagot, 20-nak vettünk cipőt, csak ettől még a területi, és társadalmi leszakadáshoz vezető okokat nem számoltuk föl. Tehát ezek nagyon rövidtávú beavatkozások lesznek, és pont ezt a fajta kitaszítottságot nem tudja az ilyen típusú beavatkozás fölszámolni. Tehát ezzel ez a problémám.

És van egy másik probléma, amit meg kell, hogy fogalmazzak, hogy úgy tünik, hogy itt most már divat lett, hogy egész egyszerüen nélkülünk, a fejünk felett születnek döntések, és megmondják, hogy majd nekünk mi lesz jó, meg mi nem lesz jó. Tehát úgy tünik, hogy mi romák a saját életünknek nem vagyunk szakértői, vagy olyan birtokosai, akik rendelkeznek felette, és hogy ez azért anomália, mert egy ilyen gettófaluban élő cigányembernek azt fogják mondani, hogy akkor vegyünk-e neked cipőt, vagy inkább vezessük be a szervezett hulladékszállítást, vagy a munkahelyeket elérő munkásbuszt indítsunk, akkor persze azt fogja mondani, hogy vegyél nekem cipöt. Közben a területi leszakadásnak nemcsak az a következménye, hogy a szociálpolitika müködésképtelenné válik, mert sem mennyiségében, sem minőségében nem tud olyan eszköztárat felmutatni, de a gazdasági és infrastrukturális hátrányok sem oldódnak föl. Mert jellemzően ezekben a válságtérségekben, és válságtelepülések közelében hiányzik a közlekedési infrastruktúra, a gazdasági infrastruktúra. Közben azt várjuk, hogy a 200 fős falu munkanélküli, szegény, és esetleg roma polgára az váltsa már meg az életét, legyen kedves többet tanulni, többet dolgozni, és találjon már munkahelyet úgy, hogy közben 50 km-es körzetben nincs gazdasági szereplö.

DÁ: A szociális állapotokról mindketten elég sötét képet festettetek, és a szociális szakemberek helyzetéröl is. Sándor emlitette elöbb a szakemberhiányt, ami nagyon fájó módon jelentkezö tendencia a felsőoktatásban is, drámaian csökken a hallgatói létszám. December van, hamarosan itt van az az idöszak, amikor a frissen érettségizők és a továbbtanulni vágyók kitöltik a felsőoktatási jelentkezési lapokat. Hogyan lehetne megnyerni az ifjúságot ennek a szakmának? Szerintetek hogyan lehet öket motiválni ennek a pályának választására?

SJ: sehogy, mert ugyanaz a helyzet, mint a pedagógusképzésnél, hogy egy kicsit olyanok a szociális munkások tömegei is, mint maguk az ügyfeleik. Tehát azért az nonszensz, hogy egy diplomás szociális munkás milyen helyzetben van. Volt olyan szociális munkás barátom, illetve van több is, akik mondjuk diplomával a zsebükben, önkormányzati segítő intézményben nettó 95.000.- Ft-ot kerestek x ledolgozott szakmai év után. Ami felháborító és mélyen igazságtalan! És hát ugye az szokott történni, hogy a legelvakultabbak, a legfanatikusabbak, a legelkötelezettebbek maradnak a pályán. Itt ugye megint csak egy olyan beavatkozásra volna szükség, hogy az állam megbecsüli az ebben a szakmában dolgozókat, akár az oktatásban a pedagógusokat is meg kellene becsülni, és a szociális segítő szakmában dolgozókat is. 
DÁ: Sándorék a nemrég újjászületö Szociális Munkások Magyarországi Egyesületében, tehát a szakma egyik érdekvédelmi szervezetében elkezdtek szervezkedni és mozgolódni ezen a területen.

MS: Próbálunk ezen a területen valamit csinálni. Nekem ezzel az a nagy gondom, hogy ahhoz, hogy mások megbecsüljék a szociális munkát, megadják nekünk a tiszteletet, ahhoz kellene, hogy maga a szociális szakma saját magának megadja a tiszteletet, és megbecsülje magát. Nem akarok itt most az elmúlt időszakból párbeszédeket fölidézni, de én abszolút azt látom, hogy már valahol a szakma maga is lemondott magáról.

Ha megnézzük akár a képesítéseknek a szabadjára engedését, már gyakorlatilag az 1/2000-ben² nem is találom meg a szociális munkást. Újra fel kellene építeni az identitást, meg azt a szakmai definíciót, amiben újjá lehetne építeni ezt az egészet. Amíg ez nincs meg, addig szerintem nem nagyon fogja senki megadni nekünk ezt a tiszteletet, vagy ezt a megbecsülést, amit várunk. Ehhez a szakmának egy kicsit magával kellene foglalkozni, reflexíven müködni, önmagára találni, egyébként nem fog működni. Azt várni, hogy majd megbecsül minket az a kormányzat, aki egyébként azokat a problémákat se szívesen látja, amikkel mi foglalkozunk, felesleges.

Azt gondolom, hogy kiindulásként a szakmának egy identitásépítést kellene csinálni, definiálni saját magát, mit is akar szociális munkásként a XXI. században, 2020-ban Magyarországon csinálni. Ebbe az identitásba kellene belekapaszkodni, és fölhúzni magunkat egy picit a saját hajunknál fogva.

DÁ: Van azért egy elég nagyszámú szakembergárda, akik nem az önkormányzati, vagy az állami rendszernek a munkatársai, hanem a civil szervezetekben vállalnak szerepet, és egyértelmüen szociális munkásnak vallják magukat, ez az identításuk.

MS: Lehet, hogy onnan kellene kezdeni az építkezést. Három nagy szektor van, ha valaki az állami szektorban, önkormányzati rendszerben dolgozik, attól ő még tarthatja magát szociális munkásnak. Sőt, lehet, hogy a jelenlegi kereteken belül megtalálja azt a lehetőséget, hogy ő szociális munkásként tudjon működni annak ellenére, hogy mondjuk, szociális rendőrként akarja őt alkalmazni a jelenlegi keretrendszer.

A másik nagy falat, ami meg szinte kisgömböcként terjed, az egyházi fenntartók köre. Ez a maga keretein belül ki fogja termelni ugyanazokat a határokat, ami a szociális munka értelmezését valamilyen szinten korlátozza. Ennek is megvannak a jelei, gondoljunk arra, hogy az egyházi fenntartóknak az állami pénzellátástól való függése alapvetően egy olyan konformitást generál, ami mindenféle kritikát el fog nyomni a kormányzati intézkedésekkel szemben. Például nem volt nehéz észrevenni, hogy abban a pillanatban, hogy elindult Gyöngyöspatán ez a romaellenes uszítás, abban a pillanatban pl. Vecsei Miklós mintha meg is szünt volna. Nem az történt, hogy kiállt volna, hogy Gyöngyöspata benne van a 300 településben, nézzük már meg, hogy ott mit lehetne csinálni, és próbáljunk meg segítő kezet nyújtani az ottaniaknak. Egyszerüen eltűnt a kommunikációs térből. Ha nem jön be a COVID,

\footnotetext{
${ }^{2}$ 1/2000. (I. 7.) SzCsM rendelet a személyes gondoskodást nyújtó szociális intézmények szakmai feladatairól és működésük feltételeiröl
} 
akkor ebben a témában egy az egyben végig is tarol mindent a kormányzat, ott jártak épp, hogy ki akartak írni egy nemzeti konzultációt erre az egész problémára. Ha onnan indulunk, hogy ha jön a pénz, akkor csöndben kell maradni, akkor gyakorlatilag az egyházi rendszeren belül a kritikus építkezés erősen korlátozott. És akkor még nem mentünk bele a vallási szempontból érzékeny témákba, például mi a család, hogy néz ki, mi az a családmodell, amit mondjuk esetleg egy szociális munkás mondjuk képviselni akar, támogat, mit lehet kezdeni az azonos nemüeknek párkapcsolatával? Milliónyi ilyen etikai és szakmai kérdést fölvethet.

Marad a civil szféra, ami gyakorlatilag az elmúlt évtizedeknek a vesztese, mert a forráselosztás szempontjából sem állnak jól, meg úgy egyébként az elaprózottságuk révén sincsenek jó helyzetben. Van 2-3 nagy szervezet, de a legtöbb civil szervezet kis társaság, ahol egy-egy szolgáltatást például saját érintettség mentén kezdenek el csinálni. Nagyon sok ismerősöm van, aki támogató szolgálatot érintettként hoz létre, és akkor így a fogyatékos személyek ellátását csinálják. Ebből a körből biztos, hogy van olyan, aki kilépve tud szociális szakmai identitást, meg szakmai tartalmat generálni, de a többség egyébként nem ebben az irányban működik, hanem egy adott problémának egy nagyon szűk spektrumon belüli megoldásán dolgozik.

Azt gondolom, hogy ebböl a háromból azért össze lehetne hozni azt, hogy legyen egy jó föltámadása a szakmának, de nem egyszerü a dolog. Nagyjából ugyanott vagyunk, mint a 20052006-os években (vagy talán még rosszabb a helyzet), amikor szakmai konferencián az egyházi, meg a civil, és az állami szektornak a képviselői szó szerint ilyen háborús helyzetet csináltak egy vitában a szektorok közötti különbségekből, hihetetlen feszültségü helyzet alakult ki. Tele vagyunk egymással szembeni sztereotípiákkal, amiknek bizonyos alapja van, mert a három rendszernek a müködése ebben a keretrendszerben sok mindenben eltér egymástól. Azt érzem, hogy az a szektorsemlegesség, aminek kellene lenni a szakmában, nincs.

DÁ: a szektorokhoz kapcsolódva kérdés, hogy milyen szinten állnak a szakmán belül az együttmüködések? Hogyan lehet a szervezetek közötti közös munkával elérni valamiféle elörelépést, a szociálpolitika alakitásában, a szakmai identitás erösitésében? Természetesen sokféle közös munka folyik itt-ott. Ami talán kiemelkedik az utóbbi idöszakban, az a lakhatással foglalkozó szervezetek együttmüködése, összehangolt munkája. Miközben mindegyikük müködik saját profilja szerint, a szociálpolitika alakitására irányuló munkájukban jelentös az együttmüködés.

MS: A saját példámat el tudom mondani, mert valami hasonlót csináltam én régen a támogató szolgálatoknál. Arról szólt anno a történet, hogy először Kecskemét városában és környékén dolgozó kollégákkal leültünk, és elkezdtünk közösen gondolkodni problémákon. Vagy találtunk megoldást vagy nem találtunk, de megállapítottuk, hogy adott problémára senki nem tudja a megoldást. Valami konklúzióra azért jutottunk ezekkel a közös gondolkodásokkal és ha volt rá lehetőség, akkor próbáltunk közösen megoldásokat találni ezekre a problémákra. Ez a közös gondolkodás hólabdaszerűen, szépen egy országos dologgá nőtte ki magát, amiben már szakmai műhelyeket szerveztünk, együttmüködéseket csináltunk. Ez egészen odáig fejlődött, hogy amikor 2011-2012-ben tervezték a büdzsét és a támogató szolgálatok költségvetését alaposan megnyírták, akkor egy országos aláírás kampányt tudtunk csinálni. 
Ami szerintem müködik, hogy ha van 1-2 tényleg hiteles ember, aki egy-egy problémába beleáll, és arra föl tud épülni egy ilyen együttmüködés a terepen dolgozó kollégák között. Egyébként nekem az volt a tapasztalatom, hogy ha próbáltuk ezt az együttmüködést formalizálni, nem volt rá szükség, sőt nem is igazából működött. Az informális, kollégák közötti együttmüködés nagyon jó munkakapcsolatokat, meg együttmüködést eredményezett, ennyi ott és akkor elegendő volt. Én egy ilyen kezdeményezésben látom most is a fantáziát: ha van közös gondolkodás a problémák mentén, kollegális szinten, akkor erre lehet építkezni, és aztán ezt föl lehet emelni magasabb szintekre is.

SJ: Én a mi egyesületünk élményeiről tudok beszámolni. Az Idetartozunk Egyesületben, amiket csinálunk, abban úgy látom, úgy érzékelem, hogy abból a szempontból nagyon szerencsésnek érzem magunkat, és hálásak vagyunk a többieknek, hogy nekünk általában sikerül egy nagyon széleskörü akcióközösséget kialakítani. Így volt ez a tankötelezettségi korhatár visszaállítására irányuló aláírásgyüjtési akciónál, és így volt ez akkor is, amikor a gyöngyöspatai gyerekek kártérítési ügyében emeltük föl a szavunkat a bíróságok függetlensége mellett. Nagyon sok roma, és legalább ugyanennyi, vagy akár még több nem roma szerveződés csatlakozott. Ezért is volt mind a két akciónk az én értékelésem szerint sikeres. Tehát meg tudtuk mutatni azt a társadalmi erőt, ami kifejtette az álláspontját ebben a két kérdésben, tehát akciószinten már jól tudunk együttmüködni más szervezetekkel. Ugye azt tudni kell, hogy mi 2012-től 2017-ig informális szerveződés voltunk, tehát kvázi egy baráti társaság, az energiáink nagy részét a szélsőjobb elleni védekezés vitte el, amikor még léteztek, meg mindenféle szélsőjobbos megfélemlítő akciók. És 2017-től vagyunk formálisan is bejegyzett egyesület, de az, amit te fölvetsz, az a szisztematikus, tervezett együttmüködés, az még hiányzik az életünkből, ezt mi is így értékeljük, hogy ezen, mondjuk az egyesületi életen belül változtatnunk kell, csak még nincs arra konkrét tervünk és stratégiánk, hogy hogyan fogjuk ezt csinálni. A hiányt, és az igényt azt érezzük, nagyon őszintén mondom. Tehát ebben nekünk konkrétan az egyesület tekintetében van hova fejlődnünk. Tavaly Urbanovszky Zsuzsa kapta az év szociális szakembere díjat. Amikor ők a Hős utcában küzdöttek, akkor mi azonnal megkerestük őket, mert nagyra tartottuk az ő munkájukat. Ma úgy hívjuk őket, hogy „Otthonvédő mozgalom”, de mi a Roma Polgárjogi Alapítványban Horváth Aladár vezetésével 15 évet dolgoztunk, a mindenféle kilakoltatások megfékezéséért, hogy elérjük azt, hogy szülessen egy olyan jogszabály, ami megtiltja a pusztán a hajléktalanságba taszító, elhelyezés nélküli kilakoltatásokat. A mai otthonvédő szervezetek, és mozgalmak, ennek az aktivitásnak az utódai, talán így is lehetne fogalmazni. Tehát, amikor az Urbanovszky Zsuzsáék küzdöttek a Hős utcában, akkor nem volt kérdéses, azonnal egyeztettünk velük, felajánlottuk a mi felgyülemlett tapasztalatainkat, a rendelkezésre álló jogi kapacitásainkat. A folyamatos szakmai és operatív egyeztetés, konzultáció lehetőségét. Tehát vannak ilyen együttmüködéseink sokféle szerveződéssel. Mondom, ebből az hiányzik - a mi, és a közösség fejlődése szempontjából is -, hogy ez egy tervezett, és szisztematikus tevékenység legyen. 
DÁ: zárszóként azért mégis üzenjetek valamit a középiskolásoknak, ami arra ösztönözheti őket, hogy jelentkezzenek szociális szakokra, mert ez egy szép szakma, jó szakma, szerethetö szakma.

SJ: az az üzenetem, hogy jelentkezzenek, mi is túléltük!

MS: Őszintén szólva megfogtál, nem tudom. Maximum azt tudnám nekik javasolni, hogy jelentkezzenek, legyenek szociális munkások, jöjjenek a szociális szakmába, és segítsenek megváltoztatni ezt a szociális szakmát, hogy arról szóljon, amiről szólnia kell.

Az interjút készitette: Darvas Ágnes 